\title{
Végső mentsvár: Az Európai Központi Bank tartós szerepvállalása az euroövezeti bankrendszer devizalikviditási zavarainak kezelésében*
}

\author{
Kiss Gábor Dávid - Tanács Gábor Zoltán - Lippai-Makra Edit - Rácz Tamás
}

A globális pénzügyi válság kirobbanását megelőzően a kulcsdevizák nemzetközi bankközi piaca beszúkült, és a piac szereplői egyre gyakrabban szembesültek devizalikviditási zavarokkal. A problémát elsőként az amerikai Federal Reserve 2007 decemberét követöen más meghatározó jegybankokkal kötött devizaswap-megállapodások sorozatával kívánta kezelni. Bár ezeket az intézkedéseket kezdetben átmenetinek tekintették, mind a mai napig jelen vannak a vezető jegybankok, és így az Európai Központi Bank gyakorlatában is. A jegybankközi devizaswap-megállapodások lehetövé teszik, hogy szükség esetén egyfajta „végsö mentsvárként”, a piacon érvényesülö kondícióknál kedvezőbb feltételek mellett biztosítsák a megfeleló mértékü devizalikviditást a bankrendszer számára. Tanulmányunkban az Európai Központi Bank által az euroövezeti bankrendszer számára rendelkezésre bocsátott devizalikviditás iránti igény alakulását vizsgáltuk 2007 és 2019 között, negyedéves adatokon, vektor-autoregresszió segítségével. Megállapítottuk, hogy a dollárban denominált devizaforrás kihelyezése az EKB tenderein leginkább abban az esetben nö meg, ha a bankrendszer nem képes piaci alapon nemzetközi forrást bevonni, amikor a dollárpiaci feszültségek nőnek, illetve ha az eszköz-arányos eredményük romlik.

\section{Journal of Economic Literature (JEL) kódok: E52, E58, E44, C22}

Kulcsszavak: végső mentsvár, devizalikviditás, devizaswap, repo, tender, bankrendszer, nemkonvencionális monetáris politika, EKB, VAR

\footnotetext{
* A jelen kiadványban megjelenő írások a szerzők nézeteit tartalmazzák, ami nem feltétlenül egyezik a Magyar Nemzeti Bank hivatalos álláspontjával.

Kiss Gábor Dávid a Szegedi Tudományegyetem Gazdaságtudományi Karának egyetemi docense. E-mail: kiss.gabor.david@eco.u-szeged.hu

Tanács Gábor Zoltán a Szegedi Tudományegyetem Gazdaságtudományi Karának pénzügy mesterszakos hallgatója.E-mail: tanacsgabor1995@gmail.com

Lippai-Makra Edit a Szegedi Tudományegyetem Gazdaságtudományi Karának tanársegédje.

E-mail: makra.edit@eco.u-szeged.hu

Rácz Tamás a Szegedi Tudományegyetem Gazdaságtudományi Karának PhD-hallgatója.

E-mail: racz.tamas@eco.u-szeged.hu
}

A kutatást az EFOP-3.6.2-16-2017-00007 azonosító számú, Az intelligens, fenntartható és inkluzív társadalom fejlesztésének aspektusai: társadalmi, technológiai, innovációs hálózatok a foglalkoztatásban és a digitális gazdaságban címú projekt támogatta. A projekt az Európai Unió támogatásával, az Európai Szociális Alap és Magyarország költségvetése társfinanszírozásában valósul meg.

A magyar nyelvű kézirat első változata 2020. április 23-án érkezett szerkesztőségünkbe.

DOI: http://doi.org/10.25201/HSZ.19.4.83106 


\section{Bevezetés}

A fejlett országok bankrendszereiben a külföldi devizában denominált forrásgyűjtés és hitelnyújtás a hatvanas évek óta vált jelentőssé. A nyugat-európai hitelintézetek forrás oldalán előbb az amerikai dollár-betétek jelentek meg, majd ezek kiegészültek az olajexportőr országok petrodollárjával (Madura 2008). Ugyanakkor napjainkban beszélhetünk már e téren olyan intézményi befektetőkről is, akik adó-optimalizációs szándékkal jelentek meg, illetve utalhatunk a tőkemenekítésből (capital-flight) származó betételhelyezésekre is (Kiss - Ampah 2018). Belátható, hogy a nemzetközi kereskedelem és a fejlődő országok intézményi gyengeségei egyaránt devizalikviditás-többletet hoznak létre a fejlett piacokon, amely utána kihitelezésre is kerül: napjainkban a dollárnak megközelítőleg 60 százalékos súlya van a devizatartalékok, a nemzetközi kötvénypiac és magánhitelezés területén, míg az eurónak 20 százalékos, a jennek és a renminbinek 5 százalék alatti a részesedése (EKB 2019). A nemzetközi bankközi piac hálózati felépítésének zavarai ${ }^{1}$ azonban komoly likviditáshiányt képesek előidézni.

A 2007-2008-as globális pénzügyi válság során a nemzetközi likvid tőke áramlása hirtelen beszúkült, illetve egyes csatornákon meg is szűnt („,sudden stop”), ami a piaci alapon történő finanszírozást abban az esetben is megnehezítette, ha az adott ország államadóssága, illetve bankrendszere korábban nem küzdött problémákkal. Míg a Nemzetközi Valutaalap (IMF) forrásai jellemzően államcsődközeli helyzetek kezelésére vehetők igénybe, az európai szuverén adósságválság során a bankmentés végrehajtására pedig jelentős mértékben az Európai Stabilitási Mechanizmus (ESM) és elődszervezeteinek hitelezése szolgált, addig a rövid lejáratú devizalikviditás biztosításának kevésbé voltak intézményesítettek a feltételei. Ezek a devizalikviditási igények jellemzően a nemzetközi pénzpiac zavaraiból fakadnak, így gyorsan jöhetnek létre, és mértékük igen változó lehet. Tanulmányunkban ennek az ad-hoc devizalikviditás-nyújtásnak a hátterét mutatjuk be az Európai Központi Bank (EKB) példáján keresztül, külön kitérve a főbb jegybankok által, valamint a regionálisan létrehozott devizacsere (swap)-megállapodásokra. Egy devizaswap-ügylet széleskörüen használható fel, többek között likviditáskezelésre, kockázatfedezésre, valamint rövid távú hozamspekulációra (Mák - Páles 2009), munkánk során azonban ezeket az ügyleteket kizárólag a jegybankok nemzetközi, devizalikviditás megszerzésére irányuló funkciójuk alapján elemezzük. A devizakitettség változásának értékelése szempontjából érdemes továbbá elkülöníteni a devizában denominált értékpapír fedezete mellett végzett repomúveleteket (ahol nem változik a kitettség) a devizaswap-múveletektől, ahol változik a devizakitettség - azonban mindkét esetben szükség van likvid eszközre.

\footnotetext{
${ }^{1}$ Lásd például: Ananda et al. (2012); Allen - Babus (2009) amerikai, vagy Berlinger et al. (2011); Banai et al. (2015) hazai bankközi piacok topológiai változásáról szóló eredményeit.
} 
Bár elsőre úgy tűnt, hogy az európai bankrendszer csak ideiglenesen fog az EKBhoz fordulni devizalikviditásért, a gyakorlat azt mutatja, hogy lassan 13 éve kell alkalmazni ezt az eszközt, sőt a 2020-as év COVID-19-válsága tovább fokozta az így allokált tőke mennyiségét. Munkánk során ezért az EKB által 2007 és 2019 utolsó negyedéve között az eurozóna hitelintézeteivel az amerikai dollárban bonyolított tenderein kihelyezett tőke változását vizsgáljuk vektor-autoregressziós modell segítségével. Ehhez a bankrendszer eurozónán kívüli, nem euróban denominált forrásainak mérlegfőösszeggel vett arányát, az EUR-USD bázis swap által jelzett dollárpiaci feszültségeket, a bankrendszer eszközarányos nyereségességét és az EKB mérlegének eszköz-oldali szerkezeti változásait elemeztük. Az elméleti modell megalapozásához előbb bemutatjuk a jegybankok közötti devizaswap-megállapodások kiépülését a vizsgált időszakban, valamint az EKB vonatkozó gyakorlatát. Ezt követően ismertetjük a felhasznált adatokat és az alkalmazott módszertant, végül az elméleti modellnél megfogalmazott intuíciók tükrében értékeljük a kapott eredményeket. Megállapítjuk, hogy bár a forrásköltségek nem, a többi változó már középtávon szignifikáns hatást gyakorolt az eurozóna hitelintézeteinek EKB-hoz fordulásában, ha devizalikviditásra volt szükségük.

\section{Elméleti háttér}

A globális pénzügyi válságot megelőzően, 2003 és 2007 között az eurozóna bankjainak összesített hitel-betét-mutatója 100 százalék feletti szinten tartózkodott, amelynek finanszírozására - komoly kötvényállomány mellett - egyre növekvő mértékben használtak pénzpiaci forrásokat (EKB 2008). Ebben a fejezetben azokat a jegybankközi swapmegállapodásokat és az eurozóna bankrendszerét érintő változásokat foglaljuk össze, amelyek a fenti állapot egyenes következményeként az EKB szerepének felértékelődéséhez vezettek el a bankrendszer stabil devizalikviditásának biztosítása terén. Az, hogy ez a szerepvállalás tartósan fennmaradt és napjainkig kíséri az EKB múködését, a jelen tanulmányban kidolgozott elméleti modellben is megjelenik.

\subsection{Jegybankok közötti swapmegállapodások}

A 2007-2008-as globális pénzügyi válság nyomán elterjedő nemkonvencionális monetáris politika eszköztárában a kötvénypiaci „végső árjegyző” funkció mellett a jegybankok hagyományos „végső hitelező"2 funkciója is kiegészült a devizában történő finanszírozás eszközével (jellemzően rövid, O/N és 3 hónap közötti lejáratokon) (BIS 2011; Seghezza 2018; Ács 2011). Egy jegybank ugyanis dönthet úgy is, hogy egy meglévő devizaforrást nem külföldi eszközbe fektet be, hanem belföldi hitelintézeteknek hitelez tovább, az azonban a devizatartalék csökkenését eredményezné. Miután a devizatartalékoknak meg kell felelniük a hitelminősítők és egyéb

\footnotetext{
2 Bár a nemzetközi szakirodalom a „lender of last resort” kifejezést használja, a repo-ügyletek tömeges alkalmazása miatt ez egy tágabb értelemben vett forrásnyújtást jelent.
} 
stakeholderek által lefektetett elvárásoknak (pl. Guidotti-Greenspan- és M2-szabályok), célszerünek tűnt a devizaforrások körének kibővítése (Obstfeld et al. 2009). Ez történhet devizában való kötvénykibocsátással (amely viszont állampapírnak minősül), devizában történő betétgyűjtéssel, illetve hitelfelvétellel (akár más jegybanktól, illetve a Nemzetközi Fizetések Bankjától), azonban likviditáshiányos piacon ez nehezebben megvalósítható. Ebben az esetben lehetséges intézményesített keretek között (IMF vagy Regionális Finanszírozási Megállapodások ${ }^{3}$ ) hitelt felvenni, illetve alternatív, ad-hoc devizaforrásokhoz (jegybankközi swap- és repo-megállapodások) folyamodni (Antal-Gereben 2011).

Egy jegybankok közötti devizacsere-ügylet során a két jegybank a saját pénznemükben nyújt hitelt a másik félnek, így egyszerre vesz fel spot és forward pozíciót ${ }^{4}$, ahol a két pozícióban szereplő árfolyam különbsége a swappont. Egy swapmegállapodás segítségével decentralizált módon oldható meg a devizalikviditáshoz jutás, ami gyorsabbnak és rugalmasabbnak tűnik egy intézményesített (pl. IMF) hitel kondícióihoz ${ }^{5}$ képest. Ennek eredményeképpen azonban a devizaswap-megállapodásoknak számos buktatója is lehet: létrehozásához szükséges egy másik jegybank ellenirányú devizaigénye; a megállapodás lejáratakor a másik szereplő dönthet a további folytatás megszűntetése mellett; a kulcsdevizákat kibocsátó jegybankok szabadon válogathatnak a lehetséges partnerek között, illetve hiányoznak a nemteljesítés elleni ${ }^{6}$ biztosítékok is (Destais 2016).

Jegybankközi ad-hoc devizaswap-megállapodások az 1920-as évektől kezdve jelentek meg a nemzetközi piacokon, jellemzően 3 hónapos futamidővel, amit 1962-től az amerikai Federal Reserve (Fed) emelt magasabb szintre a nyugati jegybankokat és a BIS-t is magában foglaló swapmegállapodások (swap-lines) hálózatának megteremtésével a Triffin-paradoxonból ${ }^{7}$ következő egyensúlytalanságok kezelése végett (Bordo et al. 2015). Ennek a középpontjában a dollár mint akkori aranyfedezetű világpénz állt. A Bretton Woods utáni időkből kiemelhető még a 2001-es dollár swapmegállapodás, ahol azonban már az EKB is megjelent a nemrég létrehozott euro kibocsátójaként.

A 2007 decemberében létrehozott átmeneti (6 hónapos) jegybankközi, kezdetben négy vezető jegybankkal (kanadai, brit, svájci jegybankok és az EKB) kötött dollárswap-megállapodás a Fed-et a nemzetközi végső hitelező pozíciójába emelte.

\footnotetext{
${ }^{3}$ Regional Financing Arrangements

${ }^{4} \mathrm{~A}$ fedezett kamatparitás által indokolt szinttől stressz hatására képes jelentősen is eltérni a piac, ahogyan azt Csávás - Szabó (2010) is megállapította. Brophy et al. (2019) ezt a jegybanki kötvényvásárlási programokból fakadó további torzításokkal egészítette ki.

${ }^{5}$ Különösen annak költségvetési és gazdaságpolitikai vonzatai miatt, ami teljesen hiányzik egy swapmegállapodásból.

${ }^{6}$ Bár ebben az esetben lehetséges repo-megállapodás kötése is.

${ }^{7}$ A dollár egyszerre volt nemzeti pénznem és nemzetközi kulcsdeviza, így míg az utóbbi szerep megköveteli, hogy a nemzetközi dollárigény kielégítéséhez az USA fizetési mérlege deficites legyen (hosszabb távon az aranytartalékok kiáramlását eredményezve), a rövid távú, belföldi gazdaságpolitikai célok ezzel ellentétesek lehetnek.
} 
Ez egészült ki 2008 márciusában a G10 országok többi jegybankjával, ezt követően 2008 szeptemberében pedig a japán jegybank csatlakozott a körhöz. A megállapodások félévente rendszeresen megújításra kerültek, míg 2010. február 1-jén a nemzetközi pénzpiacok láthatóan már nem igényelték ezt a fajta csatornát, így a jegybankok az együttmúködést lezártnak ${ }^{8}$ tekintették. Ez a fajta optimizmus azonban nem bizonyult tartósnak, miután 2010 májusában már ismét létre kellett hozniuk ${ }^{9}$ ezt a fajta átmeneti dollárswap-megállapodást (1. ábra). Az együttműködés sorozatos megújítását követően 2011 decemberére jutottak el odáig a felek, hogy már nem csupán dollárban, de a saját pénznemükben is indíthattak egymással swapügyletet ${ }^{10}$ (azaz például kanadai dollárban, fontban, jenben, svájci frankban és euróban az amerikai dollár mellett). 2013 október végére a felek számára nyilvánvalóvá vált, hogy a lassan hat éve tartó „átmeneti” swapmegállapodásokról jó ideig még nem lehet lemondani a devizalikviditás-igény átmeneti lecsillapodása ellenére sem, így a hat alapító jegybank rendelkezésre állási megállapodást (standing arrangement) ${ }^{11}$ kötött.

\section{1. ábra}

A Fed által jegybankokkal kötött swapmegállapodások értéke (heti átlag, millió dollár, logaritmikus skálán ábrázolva)

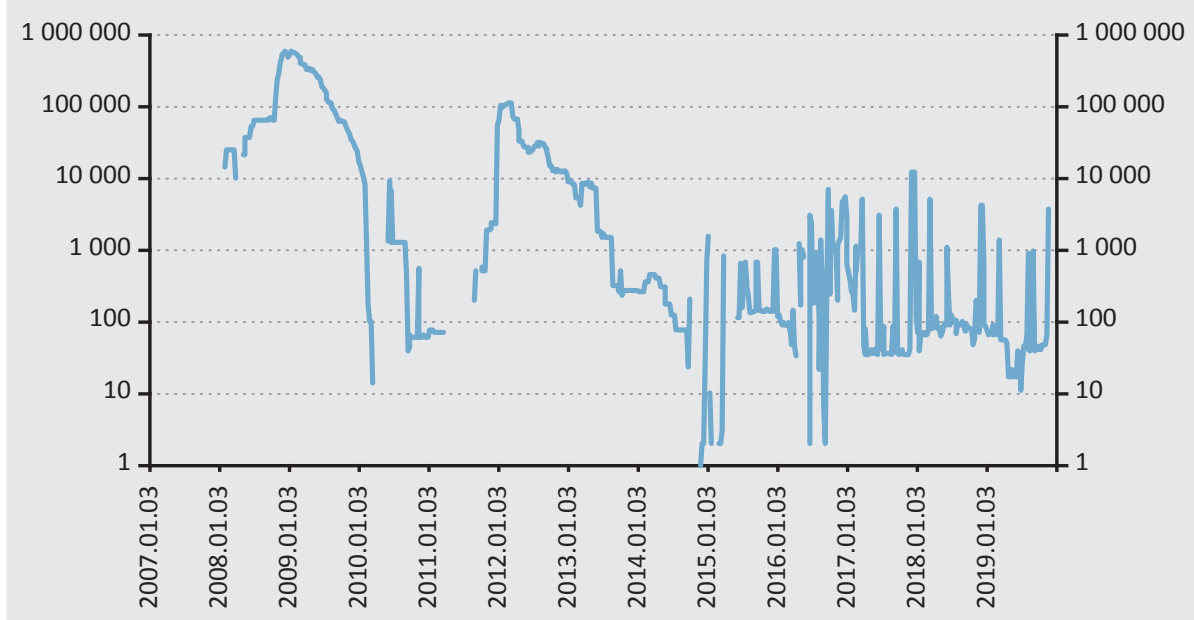

${ }^{8}$ https://www.ecb.europa.eu/press/pr/date/2007/html/pr071212.en.html

${ }^{9} \mathrm{https}: / /$ www.snb.ch/en/mmr/reference/pre_20100510_3/source/pre_20100510_3.en.pdf

${ }^{10} \mathrm{https} / / /$ www.ecb.europa.eu/press/pr/date/2011/html/pr111130.en. $\bar{h}$ tml

${ }^{11}$ http://www.ecb.europa.eu/press/pr/date/2013/html/pr131031.en.html 
A megállapodások keretében az így megszerzett likviditást a jegybankok különböző csatornákon át helyezték ki: az EKB jellemzően repo-tendereket folytatott le O/N, 1 hetes, 1 és 3 hónapos lejáratok mellett. A piaci probléma súlyosságát jól mutatja, hogy az EKB mind a mai napig végez kihelyezéseket amerikai dollárban, azaz megállapíthatjuk, hogy 2007 decembere és 2020 márciusa között nem állt teljesen helyre a pusztán piaci alapú nemzetközi finanszírozás a tartalékdevizákban sem! A vezető jegybankok feladatainak listája így mára bizonyítottan kiegészült a „végső mentsvár” funkcióval a bankrendszer megfelelő devizalikviditásának biztosítása terén is.

Egy tartalékdevizát kibocsátó jegybank esetében várható, hogy könnyen képes lesz partnert találni egy devizacsere-ügylethez, hiszen a másik szereplő számára belföldön kihitelezhető devizában nyújt hitelt. Amennyiben pedig a bankszektor likviditásigénye nem szívná fel ezt a fajta likviditást, akkor még mindig kiegészítheti vele a nemzetközi tartalékait. A helyzetet tovább árnyalják az egyes regionális jegybankközi swapmegállapodások: 2008 októberében a Fed a brazil, mexikói, dél-koreai és a szingapúri jegybankokkal is a fentiekhez hasonló megállapodásokat kötött (Seghezza 2018). Ehhez hasonlóan a skandináv (dán, norvég és svéd) jegybankok is dollárlikviditáshoz tudtak jutni. Mindez azért érdekes, mert ugyanezek a jegybankok az EKB-val is euroswap-megállapodást kötöttek 2008 őszén, miközben 2008 májusától előbb az izlandi, majd 2008 decemberétől a lett, végül 2009 májusától az észt jegybankkal is euroswap-megállapodásokat kötöttek. Ez a fajta szolidaritás utána 2010 augusztusában egy együttmúködési megállapodás ${ }^{12}$ megkötésében öltött testet, amelyben a határon átnyúló pénzügyi stabilitást, válságkezelést és bankkonszolidációt intézményesítették. Az Észak-balti Stabilitási Csoport (Nordic Baltic Stability Group) létjogosultságát a svéd bankok baltikumi dominanciája okozta, eredményességét pedig jól mutatja a balti országok euroövezethez történő csatlakozása és az együttműködés 2018-as ${ }^{13}$ megújítása.

Az EKB szintén kötött euro-font és euro-svájci frank swapmegállapodásokat 2008 és 2010 között. Az euroövezeten kívüli tagállamokkal (pl. Lengyelország, Magyarország és Lettország) kapcsolatban azonban elsősorban a fedezett, repo-megállapodásokat részesítette előnyben (euróban denominált kötvények elfogadásával) (Allen - Moessner 2010). Ezzel szemben a svájci és a lengyel jegybank 2012-ben svájci frank-zloty swapmegállapodást kötött egymással. Megállapítható, hogy a feltörekvő kis nyitott gazdaságok esetében a tőkeáramlás zavarait továbbra is leginkább a feltételhez kötött hitelnyújtás intézményes eszközével, IMF-hitel felvételével lehetett kezelni - még akkor is, ha Lengyelország a rendelkezésére bocsátott rugalmas hitelkeretet 2009 és 2017 között nem is vette igénybe. Obstfeld és szerzőtársai (2009) eredményei alapján a feltörekvő országok esetében az M2-arányos devizatartalék

\footnotetext{
12 https://www.cb.is/publications/news/news/2010/08/17/Nordic-and-Baltic-Ministries--Central-Banks-andSupervisory-Authorities-sign-Agreement-on-Financial-Stability-/

${ }^{13}$ https://www.fi.se/en/published/news/2018/new-nordic-baltic-memorandum-of-understanding/
} 
elégtelensége jól magyarázza a devizák leértékelődését, és ennek tudható be az is, hogy a megvalósuló swapmegállapodások mértéküket tekintve inkább csak szimbolikusnak tekinthetők.

A kínai jegybank által 2008 után kötött renminbiswap-megállapodások motivációja a fentiekkel ellentétben nem egy már teljeskörúen használt tartalékdeviza hozzáférhetőségében megmutatkozott sokkra adott jegybanki válasz volt, hanem inkább a Triffin-paradoxon megoldásának újabb kísérlete (Seghezza 2018). Ez alapján ugyanis a megállapodás során kapott renminbilikviditásnak a bankrendszer forrásai majd eszközei között kellene megjelennie, egyre nagyobb szerepet kapva ezzel a nemzetközi fizetőeszközök sorában (Engelberth - Sági 2017).

A globális dollárfinanszírozás egyszerre függ az amerikai és nem amerikai (jellemzően japán, egyesült királyságbeli, kanadai, francia, német és holland) bankok múködésétől. Míg a japán bankok esetében Aldasoro et al. (2019) jelentős növekedést, a dollárban denominált eszközök közel megduplázódását tapasztalta 2007 és 2017 között a hagyományos kereskedelmi banki aktivitás élénkülésével, addig az európai bankok esetében az eszköz és forrás oldal több mint megfeleződött ez alatt az idő alatt, és a rövid távú arbitrázsügyleteket kezdték előnyben részesíteni. A nem amerikai globális bankok dollárban történő finanszírozása alapvetően az amerikai pénzpiaci alapokon keresztül érkezik, amelyek kisebb mértékben repo- és nagyobb mértékben nem repo-jellegư ${ }^{14}$ csatornákat használtak a 2010-es évek során az egyre koncentráltabbá váló piacon. Ezen alapok számára a Fed overnight reverz repo eszköze jelenti a legbiztonságosabb befektetési alternatívát a rövid lejáratú államkötvények mellett, a nem amerikai bankokkal kötött pozíciónak tehát e fölötti prémiumot kell biztosítania.

\subsection{Az EKB devizakihelyezései}

2007 őszén az európai bankrendszer nem pusztán csak komoly tôkeáttétellel rendelkezett amerikai párjánál, de jelentős amerikai kitettségekkel rendelkezett az eszköz oldalon is (Pelle - Végh 2019). A banki mérleg eszköz oldalán szereplő nemzetközi devizajövedelemmel rendelkező vállalatok és egyéb, belföldi devizajövedelmekkel rendelkező szereplők, valamint a devizaforrások aránya határozza meg a devizanem-eltérés (currency mismatch) mértékét egy hitelintézet esetében (Destais 2016; Mák - Páles 2009). Forrás oldalon belföldi vagy külföldi intézményi befektetők devizabetétjei, devizában kibocsátott rövid lejáratú kötvények vagy repo-ügyletek szerepelnek, a lejárati transzformáció miatt gyakori megújítási igénnyel.

\footnotetext{
${ }^{14}$ Rövid távú értékpapírok, mint például: kereskedelmi értékpapírok (commercial paper), letéti jegyek (certificate of deposits), eszközfedezetű kereskedelmi értékpapírok.
} 
A devizalikviditás megújítása különösen problémás lehet, ha a devizaforrások súlya relatíve magas a mérlegen belül $\left(\frac{L_{n E Z, t}}{T L_{t}}>0\right)$. Páles et al. (2010) például a külföldiekkel kötött derivatív pozíció változását a nettó finanszírozási igényből vezeti le a nem adóssággeneráló tőkebeáramlás, a forintban és devizában fennálló adósság, a bankrendszer tényleges nyitott pozíciója és a belföldi magánszektorral kötött derivatív pozíció különbségeként. Bár a szakirodalom a devizaforrások felhasználását jellemzően a fejlődő országok esetében a devizaleértékelések ellentmondásosságának ismertetésekor említi meg (lásd például Frankel 2011), de mint az előző alfejezetben is látható, a devizanem-eltérés a fejlett piacokon is problémát okozhat.

Miután egy jegybankok közötti swapmegállapodás mögött a fedezetet ${ }^{15}$ Destais (2016) szerint a hitelintézeti felhasználás minősége, a visszafizetés képessége teremti meg, így ez a hitelesség végső soron makroprudenciális kérdés (Baker 2013). Az eszközarányos nyereség $\left(R O A_{t}\right)$ mértéke így közvetlenül hatást gyakorolhat arra, hogy egy-egy bank mennyire tekinthető kívánatosnak a nemzetközi bankközi piacon, ha devizalikviditást szeretne szerezni. Racionális piaci szereplők esetén egy romló ROA a jegybanki devizaaukciók irányába lökheti a piacot. Ez a fajta „viszolygás” a nemzetközi dollárpiac feszültségeiből is fakadhat, amelyet leghatékonyabban a két kulcsdeviza, a dollár és az euro közötti bázisswap változása $\left(b S_{\left.3 M, \frac{E U S}{U D}\right)}\right)$ képes megragadni, miután Kick et al. (2018) igazolta az amerikai finanszírozási környezet hatékony begyürüzését az eurozónába. Munkájuk során a német bankok esetében érvényesültek a Fed nemkonvencionális lépéseinek hatásai a dollárban történő finanszírozás esetében. A 2. ábra alapján megállapíthatjuk, hogy az EKB-nak elsősorban amerikai dollárban kell devizarepo-tendereket lebonyolítania, míg a svájci frank megjelenése epizodikusnak bizonyult. Munkánk szempontjából ezért a továbbiakban az EKB által tendereken kihelyezett dollárlikviditás $\left(K_{U S D, t}\right)$ változására fókuszálunk.

\footnotetext{
${ }^{15}$ Piaci alapú swapügylet esetében a fedezetelhelyezés követelménye fennáll, az $i$ időpontonként devizában lejáró $V O L_{i}$ még le nem járt összegű szerződésre vonatkoztatva a teljes nettó swapállományra vonatkozó margin call értéke:

$$
M C_{t}=\sum_{i=0}^{N_{t}} \frac{S_{t}-S_{0, i}}{S_{t}} \cdot V O L_{i},
$$
}

ahol $S_{0, i}$ az egyes $i$ ügyletek kötéskori azonnali árfolyama, $s_{t}$ a spot árfolyam, $N_{t}$ az adott időpontban le nem járt ügyletek száma (Páles et al. 2010). 


\section{2. ábra \\ Az EKB repo-tenderein kihelyezett amerikai dollár és svájcifrank-likviditás alakulása 2007 és 2020 között (millió euro)}

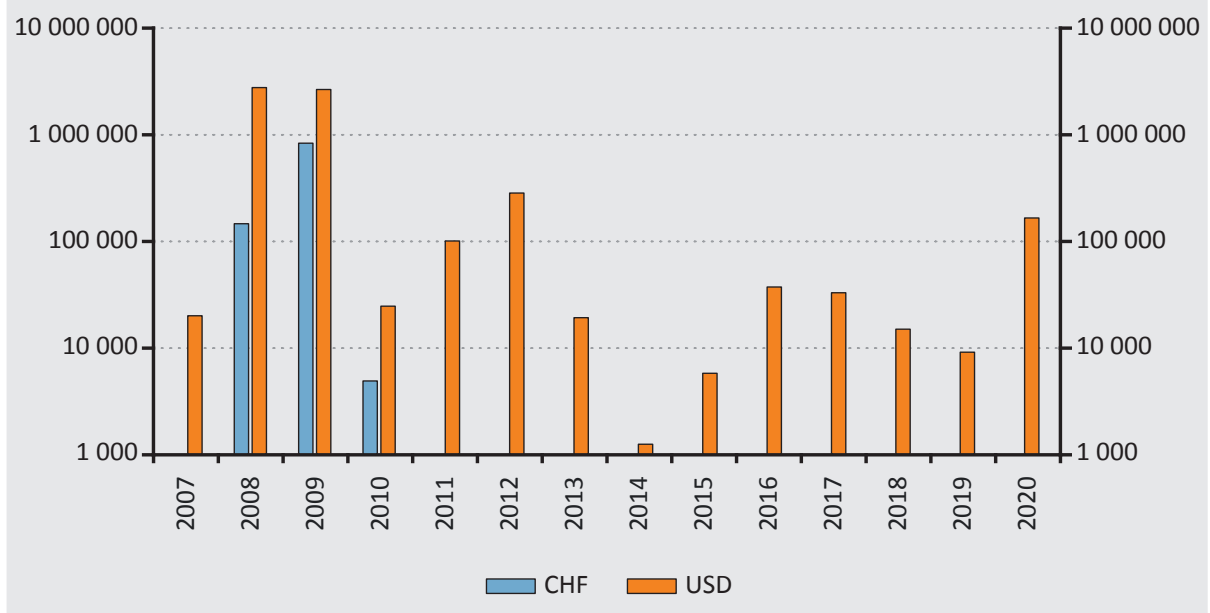

Forrás: Az EKB adatai alapján szerkesztve

Az EKB által az eurozónán belül nyújtott devizalikviditás témaköre nem különösebben vizsgált terület a szakirodalomban, sokkal népszerübb téma a határon átnyúló, tartalékdevizában történő hitelezés elemzése. Alvarez et al. (2017) a különböző (1 hetes, 1 és 3 hónapos) lejáratú jegybankközi devizaswap-megállapodások esetében a globális válságjelenségek lecsengését követően a hosszabb lejáratok fokozatos kivezetését írta le, kiemelve, hogy az EKB az eurozóna bankrendszere számára dollárlikviditást döntően repo-tenderek keretében, megfelelő fedezet ellenében nyújtott. Ez utóbbi esetben tehát nem beszélhetünk a devizakitettség változásáról, míg egy devizaswap-ügylet esetében igen. Utóbbiak iránt a piaci igény azonban jelentősen lecsökkent a 2009-es évtől.

Takáts - Temesvary (2020) is elsősorban a határon átnyúló devizahitelezés esetében megjelenő monetáris politikai transzmissziós hatásokra fókuszál, kiemelve, hogy a monetáris politika akkor is hat a devizában történő, határon átnyúló hitelezésre, ha sem a hitelező, sem az adós nem devizabelföldi. Másfelől viszont ennek a fajta hitelezésnek elenyésző a bankközi szerepe, alapvetően nem banki szereplők jelentek meg adósként. Hozzájuk hasonlóan Avdjiev és szerzőtársai (2016) az euróban bonyolított, határon átnyúló hitelezést vizsgálták, mellékesen megállapítva egyúttal a dollár 30 százalékos részesedését az eurozónában ezen a téren. Modelljükben hitelezést leíró változók mellett megjelent a devizaárfolyam is a bankok részvényárfolyamai és a szuverén kockázat mellett. Munkájukban megállapították, hogy a nemzetközi dollárban denominált hitelezési hálózat mellett létezik egy szerényebb, ámde az EKB nemkonvencionális monetáris politikája nyomán meglóduló, euróban denominált 
hitelezési hálózat is. Ivashina és szerzőtársai (2015) azonban kimondottan az európai bankok dollárban történő hitelezését vizsgálva állapították meg, hogy az euróban történő hitelezés térnyerése az általuk nyújtott hitelek minőségének a romlásával volt párhuzamos. Ezzel párhuzamosan ők is kiemelik a hagyományos piaci csatornák beszúkülését, ami drágává tette a dollárlikviditáshoz jutást. Albrizio et al. (2020) a határon átnyúló dollárban történő hitelezés csökkenését a Fed exogén szigorításából fakadó monetáris sokkjából eredezteti. Emellett Aizenman et al. (2020), valamint Seghezza (2018) paneladatokon, behatóan vizsgálta a nemzetközi devizatartalékok összetételének és relatív méretének makrováltozókkal való kapcsolatát, külön vizsgálva a swap-megállapodások hatását is, azonban a szerzők nem elemzik azt a konkrét igényt, amelyet maguk a hitelintézetek támasztanak jegybankjukkal szemben devizalikviditás szerzésének motivációjával.

\subsection{Elméleti modell}

A szakirodalom összefoglalása során megállapítottuk, hogy a jegybankok közötti swapmegállapodások motivációját az jelentette, hogy a kereskedelmi bankok csak nehezen voltak képesek devizaforráshoz jutni a nemzetközi bankközi piacokon. Ennek a devizalikviditás-éhségnek a kiszolgálására a jegybankok a nemzetközi swapmegállapodásokon keresztül megszerzett likviditást helyezték ki tendereken keresztül a saját bankrendszerüknek. Ezt az adott negyedévben kihelyezett dollárlikviditásnak a teljes időszakban mért összes kihelyezéshez viszonyított arányát jelöli $\frac{K_{U S D, t}}{\sum K_{U S D}}$ a modellünkben eredményváltozóként. Az eurozóna hitelintézeteinek eurozónán kívüli forrásainak mérlegfőösszeghez viszonyított aránya $\left(\frac{L_{n E Z, t}}{T L_{t}}\right)$ jól jellemzi a bankrendszer külső kitettségét. A dollárpiaci feszültségek indikátorául a 3 hónapos EUR-USD bázisswapot ${ }^{16}$ használjuk $\left(b S_{\left.3 M, \frac{E R}{U S D}\right)}\right)$, amelynek negatív értéke a dollárban történő finanszírozás növekedésére utal. Az érintett hitelintézetek nyereségességét az eszközarányos nyereség $\left(R O A_{t}\right)$ segítségével emeltük be a modellbe. Az EKB aktívvá váló értékpapírpiaci $\left(S_{t}\right)$ és hitelkihelyezési $\left(L_{t}\right)$ gyakorlatát a jegybanki mérleg szerkezetének átrendeződését mérő, nemzetközi tartalékkal $\left(F X_{t}\right)$ arányosító $\left(\frac{L_{t}+S_{t}}{F X_{t}}\right)$ mutatóval mértük.

A tőkeáramlásokban az üzleti ciklusok változása nyomán megjelenő töréseket az eurozónában megjelenő recesszió $\left(d_{E Z r, t}\right)$ dummy változójával reprezentáltuk. Másfelől a regressziók hibatagjainak normális eloszlásának biztosítására célszerű volt beléptetni egy, a dollár likviditás nullára esését reprezentáló dummy változót $\left(d_{\text {out }, t}\right)$.

\footnotetext{
${ }^{16}$ Currency Basis Swap: 3M EURIBOR/3M USD LIBOR, ICAP
} 
Munkánk során a fenti változókat vizsgáljuk az alábbi elméleti modell segítségével 2007 4. és 2019 4. negyedéve ( $t=1: 49$ ) között:

$\Delta \frac{K_{U S D, t}}{\sum K_{U S D}}=\omega+\beta_{1} \Delta \frac{L_{n E Z, t}}{T L_{t}}+\beta_{2} \Delta \frac{b S_{3 M, \frac{E U R}{U S D}, t}}{100}+\beta_{3} \Delta R O A_{t}+\beta_{4} \Delta \frac{L_{t}+S_{t}}{F X_{t}}+\beta_{5} d_{E Z r, t}+\beta_{6} d_{\text {out }, t}$

Ebben a modellben az alábbi intuitív várakozásokat fogalmazhatjuk meg az egyes koefficiensekkel kapcsolatban: a növekvő külső kitettség azt jelentheti, hogy a hitelintézetek képesek piaci alapon forrást bevonni, ezért várhatóan kevésbé veszik igénybe az EKB dollár-likviditást allokáló tendereit, így a $\beta_{1}<0$ érték várható. $A$ devizabázisswap csökkenő szintje a bankok fokozódó likviditáséhségét mutatja, ami ösztönzi az EKB-t a dollárlikviditás-kihelyezés fokozására $\left(\beta_{2}<0\right)$. A ROA esése esetén várható, hogy a bankok sokkal inkább támaszkodni fognak egy piacinál kedvezményesebb finanszírozási formára, így itt $\left(\beta_{3}<0\right)$ negatív koefficienst várunk. A jegybank által végzett egyre komolyabb hitel- és értékpapírpiaci beavatkozás a devizában történő likviditás kihelyezésre utal $\left(\beta_{4}>0\right)$. Ezeknek a várakozásoknak a megjelenésérére lehet számítani az impulzusválasz-függvények és a varianciadekompozíciók szintjén is. Az elméleti modell tesztelése Eviews 11 szoftver segítségével készült.

\section{Adatok és módszertan}

\subsection{Adatok}

A vezető jegybankok dollárban indított swap-megállapodásai 2007 decemberétől kaptak komoly lendületet, így a vizsgált minta 49 negyedévet fed le 2007 és 2019 utolsó negyedévei között. A felhasznált adatok forrásai az alábbiak voltak: a devizatendereken történő hitelkihelyezésekre vonatkozó információkat az EKB devizában denominált nyílt piaci múveleteket listázó adatbázisából ${ }^{17}$ töltöttük le, majd az egyedi tenderek adatait aggregáltuk negyedéves szintre az elméleti modell alfejezetben bemutatott módon. Az eurozóna hitelintézeteinek mérleg- és ROA-adatait az EKB vonatkozó statisztikai adatbázisából töltöttük le ${ }^{18}$. A devizabázisswap idősort a Refinitiv Eikon adatbázisából töltöttük le. Az eurozóna recessziós negyedéveit szimbolizáló dummy változó az Európai Bizottság adatbázisa ${ }^{19}$ nyomán készült.

\footnotetext{
${ }^{17}$ https://www.ecb.europa.eu/mopo/implement/omo/html/top_history.en.html

${ }^{18} \mathrm{http}: / /$ sdw.ecb.europa.eu/browse.do?node $=9691316$

${ }^{19} \mathrm{https}: / /$ ec.europa.eu/eurostat/cache/bcc/bcc.html
} 


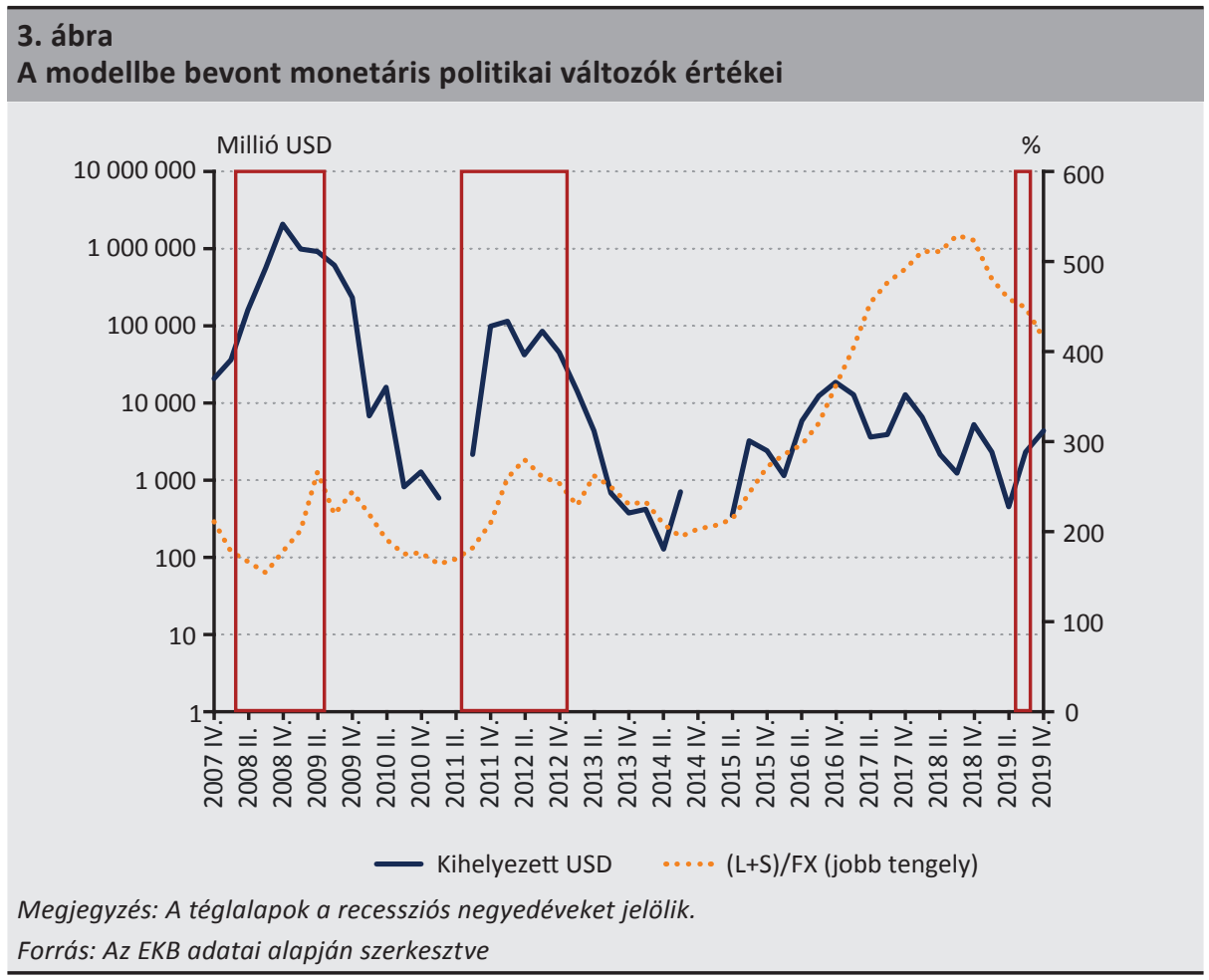

A 3. ábra alapján látható, hogy a kihelyezett dollárlikviditás csúcspontja túlnyomórészt a 2008 és 2010-es évekre esett, melyet egy második hullám követett 2011 végétől 2014 közepéig, majd 2015 után egy alacsony szinten stabilizálódott. Ezzel párhuzamosan ugrott meg az EKB hitelezési és értékpapír-vásárlási aktivitása a 2010es évek első felében, azonban jól látható, ahogyan a QE bejelentését követően az évtized felében jelentős növekedésnek indult az $\frac{L_{t}+S_{t}}{F X_{t}}-$ mutató.

A 4. ábrán látható eszközarányos nyereség értékének bezuhanása jól követte a gazdasági ciklusok hullámzását, miközben a bankszektor külső forrásainak mérlegfőöszszeghez viszonyított aránya folyamatosan csökkent a vizsgált időszak során, a kezdeti 15 százalékról 10-11 százalék közelébe. Jól látható, hogy a dollárban történő finanszírozási zavarok jellemzően a recessziós időszak elején jelentek meg, azonban a 3 hónapos EUR-USD bázisswap végig a negatív tartományban tartózkodott. 

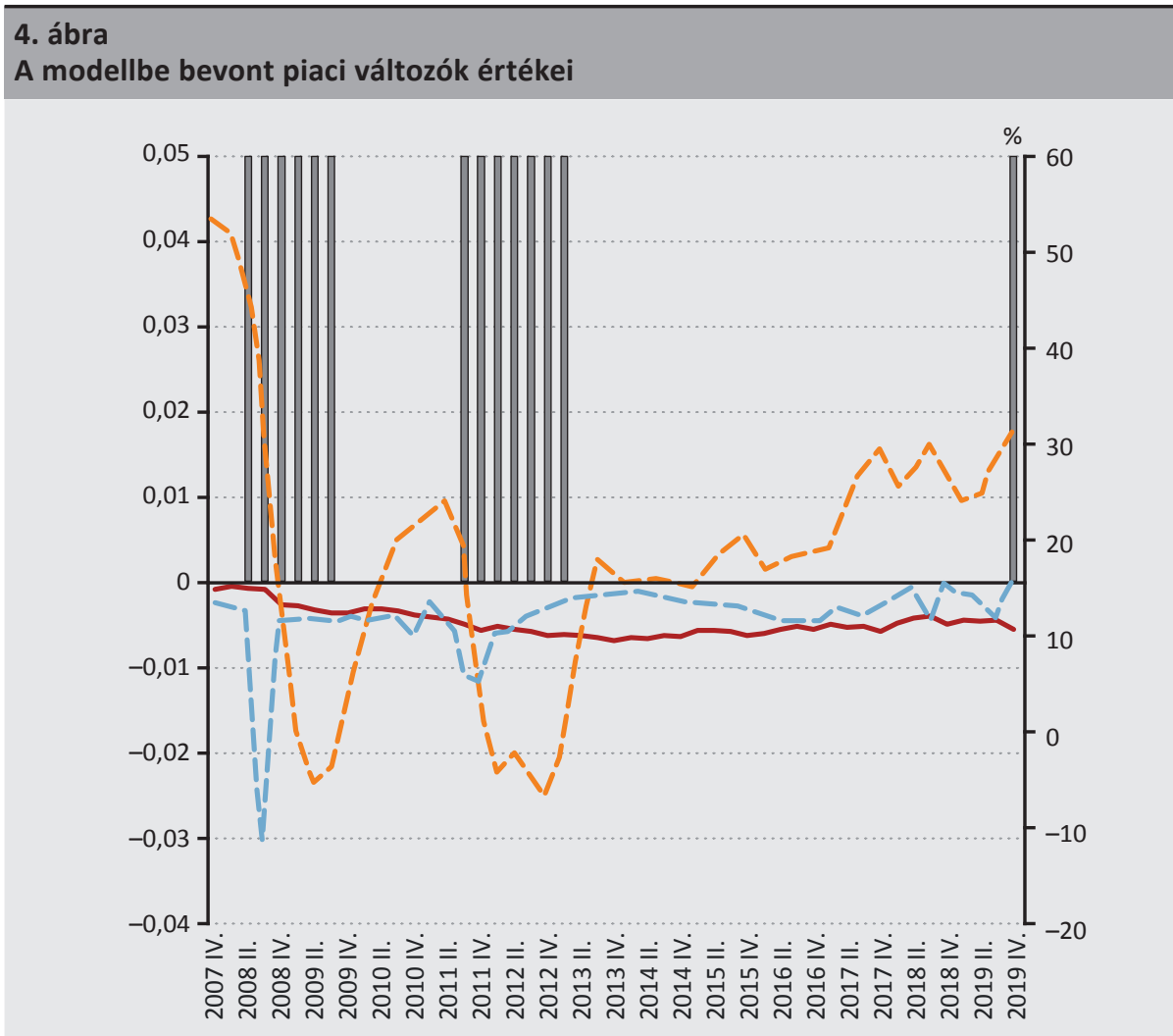

$$
\begin{array}{ll}
\square \text { Dummy_eurozóna recesszió } & -- \text { EURCBS3M } \\
& \text { Külső forrás/MFÖ (jobb tengely) }
\end{array}
$$

Forrás: Refinitiv Eikon, Európai Bizottság és EKB alapján szerkesztve

\subsection{Módszertan}

A vektor-autoregresszív (VAR) folyamatok egy kisebb mennyiségú idősoros változó adatgeneráló folyamatát jellemzik, ahol minden változó esetén egy előzetes (a priori) endogenitást feltételezünk, és figyelembe vesszük azok dinamikáját. Ez az eljárás rögzíti az $N$ számú idősoros változók halmazának dinamikus interakcióit: $y_{t}=\left(y_{1 t}, \ldots, y_{K t}\right)^{\prime}$. Az alap VAR modell az alábbi redukált (2) formában írható le Lütkepohl - Kratzig (2004) alapján:

$$
y_{t}=A_{1} y_{t-1}+\cdots+A_{p} y_{t-p}+\varepsilon_{t}
$$

ahol az $y_{t}$ a modellváltozókat tartalmazó (Nx1)-es vektor, az $F_{i}$ egy $(N x N)$-es autoregressziós koefficienseket tartalmazó mátrix és az $\varepsilon_{t}=\left(u_{1 t}, \ldots, u_{K t}\right)^{\prime}$ a nem megfigyelt hibatag, amely (Nx1) -es Gauss-eloszlású, diszkrét reprezentációjú fehérzaj-folyamatot tartalmazó vektor, valamint $\varepsilon_{t} \sim\left(0, E\left(u_{t}, u_{t}{ }^{\prime}\right)\right)$ egy pozitív definit kovarianciamátrix. $A z$ input változók esetében elvárás a gyenge stacionaritás, míg az egyenlet hibatagjai 
esetében az autokorreláció hiánya (Ljung-Box $p>0,05$ minden késleltetésre vagy $1,85<$ Durbin-Watson $<2,15$ ) és a normális eloszlás (Jarque-Bera-teszt $p>0,05$ ) a kívánatos.

A (2) egyenlet felírása során a paraméterek többféle restrikciója is elképzelhető: a Cholesky-féle felírás során a rövid távú restrikcióval a sokkok egymásutániságát, míg a Blanchard-Quah-féle hosszú távú restrikcióval a sokk megjelenését írhatjuk le. Ehhez először be kell vezetni a redukált VAR-forma strukturális (3) változatát ( $p$ késleltetés és három változó mellett az $A$ és $A^{s}$ strukturális koefficiensekkel):

$$
A y_{t}=A_{1}^{s} y_{t-1}+\cdots+A_{p}^{s} y_{t-p}+B u_{t} \text {, ahol } \varepsilon_{t}=A^{-1} B u_{t} \text { és } S=A^{-1} B \text {. }
$$

A Cholesky-restrikció során (4) feltételezzük, hogy bizonyos koefficiensek értéke nulla, és az $u_{1 t}$ hatással van a többi változóra egyidejüleg azonnal, míg az $u_{2 t}$ csak a 2. és 3. változóra hat egyidejűleg, míg $u_{3 t}$ csak a harmadikra:

$$
\varepsilon_{t}=S u_{t}=\left[\begin{array}{ccc}
s_{11} & 0 & 0 \\
s_{21} & s_{22} & 0 \\
s_{31} & s_{32} & s_{33}
\end{array}\right]\left[\begin{array}{l}
u_{1 t} \\
u_{2 t} \\
u_{3 t}
\end{array}\right]
$$

Ezzel szemben a Blanchard - Quah (1989)-féle hosszú távú restrikció (5) során a sokkot csak az F-mátrix azon sorában keresi meg, ahol a változó megjelenik és a sokk kumulált hosszú távú hatása nulla és $\Psi$ a hosszú távú multiplikátor $(F=\Psi S)$ :

$$
\left(I-A_{1}-\cdots-A_{p}\right)^{-1} \varepsilon_{t}=\Psi \varepsilon_{t}=F u_{t} \text { és } F=\left[\begin{array}{ccc}
f_{11} & 0 & 0 \\
f_{21} & f_{22} & 0 \\
f_{31} & f_{32} & f_{33}
\end{array}\right], \text { míg } S=\left[\begin{array}{lll}
s_{11} & s_{12} & s_{13} \\
s_{21} & s_{22} & s_{23} \\
s_{31} & s_{32} & s_{33}
\end{array}\right] \text {. }
$$

A hosszú távú hatásokat leíró F-mátrix felépítése (1. táblázat) Eviews-program használata esetén egyúttal meghatározta a VAR-modellbe betöltött változók sorrendjét ${ }^{20}$ is - tekintettel arra, hogy lesz egy olyan sokk, amely mindegyik változóra hatni fog, továbbá a sorrend végén szereplő változó lesz az, amelyik csak saját magára hat. Az EKB mint vezető jegybank dollárlikviditás-kihelyező tendereiből érkező sokkoknak hatnia kell a többi, modellbe bevont változóra, máskülönben a hatásosságuk megkérdőjelezhető lenne. Az EURUSD bázisswapráta sokkjai hosszú távon azonban már nem befolyásolhatják érdemben a kihelyezett összeg alakulását $\left(f_{12}=0\right)$. A bankrendszer eurozónán kívüli kitettségének sokkjai számára a swapráta és az EKB likviditáskihelyezései külső adottságként értelmezhetők, így azokra a hosszú távú hatása nullának tekinthető $\left(f_{13}=0, f_{23}=0\right)$. A jegybanki mérleg eszköz oldali felépítésének változása a teljes, konvencionális és nemkonvencionális eszköztár alkalmazását leképezi (leszámítva a tőkeáttétel esetleges változásait), azonban jel-

${ }^{20}$ Esetünkben ez az alábbi script futtatását jelenti:

var var1.Is 15 dkih_usd deurcbs3m dez_kivuli_forras dlsfxdroa @ cdummy_ez_recdummy_outlier 
legénél fogva ez nem képes leírni sem a kihelyezett dollárlikviditás, sem a swapráta, sem a bankrendszer külső kitettségének alakulását $\left(f_{14}=0, f_{24}=0, f_{34}=0\right)$. Normális üzletmenet során sem a monetáris politika vitele, sem a piaci finanszírozási feltételek szempontjából nem cél a bankrendszer eszközarányos eredményének $(R O A)$ hosszú távú figyelembevétele $\left(f_{15}=0, f_{25}=0, f_{35}=0, f_{45}=0\right)$.

\begin{tabular}{|c|c|c|c|c|c|c|}
\hline \multicolumn{7}{|c|}{$\begin{array}{l}\text { 1. táblázat } \\
\text { Hosszú távú hatásokat tartalmazó F-mátrix felépítése }\end{array}$} \\
\hline & & \multicolumn{5}{|c|}{ sokk } \\
\hline & & $\Delta \frac{K_{U S D, t}}{\sum K_{U S D}}$ & $\Delta \frac{b S_{3 M, \frac{E U R}{U S D}}}{100}$ & $\Delta \frac{L_{n E Z, t}}{T L_{t}}$ & $\Delta \frac{L_{t}+S_{t}}{F X_{t}}$ & $\triangle R O A_{t}$ \\
\hline \multirow{5}{*}{ 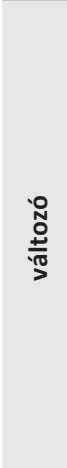 } & $\Delta \frac{K_{U S D, t}}{\sum K_{U S D}}$ & $f_{11}$ & 0 & 0 & 0 & 0 \\
\hline & $\Delta \frac{b S_{3 M, \frac{E U R}{U S D}}}{100}$ & $f_{21}$ & $f_{22}$ & 0 & 0 & 0 \\
\hline & $\Delta \frac{L_{n E Z, t}}{T L_{t}}$ & $f_{31}$ & $f_{32}$ & $f_{33}$ & 0 & 0 \\
\hline & $\Delta \frac{L_{t}+S_{t}}{F X_{t}}$ & $f_{41}$ & $f_{42}$ & $f_{43}$ & $f_{44}$ & 0 \\
\hline & $\triangle R O A_{t}$ & $f_{51}$ & $f_{52}$ & $f_{53}$ & $f_{45}$ & $f_{55}$ \\
\hline
\end{tabular}

Impulzusválasz-függvények alatt egy adott modellváltozót érintő egységnyi sokk hatását értjük, ahol az $i$ változó sokkja $j$ változóra a többi változó állandóságát feltételezve egyszerúen az elemek sorrendje az $i$ sorban és $j$ oszlopban, a $C_{k}=\frac{d y_{t}}{d \varepsilon_{t-k}}$ mátrixban.

A varianciadekompozíció lehetővé teszi annak a meghatározását, hogy mely sokkok meghatározóak bizonyos változók rövid és hosszú távú alakulásában, azaz i változó bizonytalanságának mekkora hányada tulajdonítható a j-edik sokknak $h$ periódus után:

$v D_{i, j, h}=\frac{\sum_{k=0}^{h}\left(k c_{i, j}\right)^{2}}{\sum_{k=0}^{h} \sum_{l=1}^{n}\left(k c_{i, l}\right)^{2}}$.

\section{Eredmények}

Az elméleti modell nyomán összeállított számítások eredményei három lépésben kerülnek bemutatásra: először a bemeneti változók logaritmikus változásainak alapstatisztikáit mutatjuk be, majd a VAR illesztések nyomán kapott egyenleteket és a hibatagok autokorrelálatlanságát és normális eloszlását vizsgáló tesztek eredményét ismertetjük. Végül a kapott impulzusválasz-függvényeket és a varianciadekompozíciókat ábrázoljuk. 


\subsection{Alapstatisztikák}

Ahogyan a 2. táblázatból is látható, a VAR-modellbe kizárólag stacioner változók kerültek beemelésre, amelyek az esetek egy részében normális eloszlásúnak bizonyultak. A kihelyezett dollárlikviditás és a devizabázisswap esetében tapasztalt kiugró kurtózist a dummy változók hivatottak majd kompenzálni.

\begin{tabular}{|c|c|c|c|c|c|c|c|c|}
\hline \multicolumn{9}{|c|}{$\begin{array}{l}\text { 2. táblázat } \\
\text { A bemeneti változók alapstatisztikái }\end{array}$} \\
\hline Teszt & \multicolumn{4}{|c|}{ Centrális momentumok } & \multirow{2}{*}{$\begin{array}{l}\text { Normális } \\
\text { eloszlás } \\
\text { Jarque- } \\
\text { Bera (p) }\end{array}$} & \multirow{2}{*}{$\begin{array}{c}\begin{array}{c}\text { Auto- } \\
\text { korreláció }\end{array} \\
\text { Ljung- } \\
\text { Box (p) }\end{array}$} & \multirow{2}{*}{$\begin{array}{c}\begin{array}{c}\text { Hetero- } \\
\text { szkedaszti- } \\
\text { citás }\end{array} \\
\begin{array}{c}\text { ARCH-LM } \\
\text { (p) }\end{array} \\
\end{array}$} & \multirow{2}{*}{$\begin{array}{l}\begin{array}{l}\text { Egység- } \\
\text { gyök }\end{array} \\
\text { ADF (p) }\end{array}$} \\
\hline változó & átlag & ferdeség & csúcsosság & kurtózis & & & & \\
\hline$\Delta \frac{K_{U S D, t}}{\sum K_{U S D}}$ & 0,0000 & 0,0468 & 1,8711 & 20,8573 & 0,0000 & 0,4482 & 0,6911 & 0,0000 \\
\hline$\Delta \frac{L_{n E Z, t}}{T L_{t}}$ & $-0,0049$ & 0,0507 & 0,0019 & 2,6201 & 0,7937 & 0,2202 & 0,1994 & 0,0039 \\
\hline$\triangle R O A_{t}$ & $-0,0044$ & 0,0618 & $-1,2076$ & 5,7197 & 0,0000 & 0,0000 & 0,0014 & 0,0022 \\
\hline$\Delta \frac{L_{t}+S_{t}}{F X_{t}}$ & 0,0494 & 0,2606 & 0,0852 & 2,3245 & 0,5453 & 0,0157 & 0,0232 & 0,0001 \\
\hline$\Delta \frac{b S_{3 M, \frac{E U R}{U S D}}}{100}$ & 0,0035 & 0,5821 & $-0,2699$ & 18,5860 & 0,0000 & 0,0044 & 0,3041 & 0,0000 \\
\hline
\end{tabular}

\subsection{VAR-modell}

A VAR-modell késleltetését egyfelől az információs kritériumok (a Schwarz IC 5 negyedéves késleltetést javasolt) mentén, másfelől a hibatagok normális eloszlása és autokorrelálatlansága alapján határoztuk meg. Az AIC és HQ kritériumok 6 negyedév késleltetést javasoltak, azonban azok a modellek nem rendelkeztek normális eloszlású hibatagokkal, így az 5 negyedéves késleltetésű modell mellett döntöttünk.

Ahogyan az a 3. táblázatból is látható, az autokorrelációt vizsgáló LM-teszt szerint a VAR-egyenlet hibatagjai megfelelnek az autokorrelálatlanság kívánalmainak, és a Jarque-Bera-teszt alapján normális az eloszlásuk is. A strukturális modell S- és F-mátrixát a Melléklet 4. táblázata tartalmazza. 


\begin{tabular}{|c|c|c|c|}
\hline \multicolumn{4}{|c|}{$\begin{array}{l}\text { A kétféle VAR-egyenlet hibatagjainak vizsgálata: autokorrelálatlanság és normális } \\
\text { eloszlás }\end{array}$} \\
\hline & & késleltetés & p-érték \\
\hline \multirow{12}{*}{ LM-teszt } & \multirow{6}{*}{ h-késleltetés } & 1 & 0,3037 \\
\hline & & 2 & 0,9204 \\
\hline & & 3 & 0,7095 \\
\hline & & 4 & 0,8209 \\
\hline & & 5 & 0,2207 \\
\hline & & 6 & 0,8137 \\
\hline & \multirow{6}{*}{ 1:h késleltetés } & 1 & 0,3037 \\
\hline & & 2 & 0,4463 \\
\hline & & 3 & NA \\
\hline & & 4 & NA \\
\hline & & 5 & NA \\
\hline & & 6 & NA \\
\hline \multicolumn{2}{|c|}{ Jarque-Bera } & Joint & 0,7959 \\
\hline \multicolumn{4}{|c|}{ Megjegyzés: NA: nincs adat } \\
\hline \multicolumn{4}{|c|}{ Forrás: Eviews 11 szoftverrel szerkesztve } \\
\hline
\end{tabular}

\subsection{Impulzusválasz-függvények és varianciadekompozíció}

A strukturális VAR-modellben alkalmazott hosszú távú restrikciók segítségével számított kumulált impulzusválasz-függvényeken (5. ábra) a dollárkihelyezések folyamatos öngerjesztő változása mellett megfigyelhető a kereskedelmi banki mérlegekben található eurozónán kívüli források változásának 5 negyedév után szignifikanciáját veszítő negatív hatása. Az arány növekedését az EKB dolláraukcióinak csökkenő igénybevétele kísérte. Azaz ilyen esetekben a bankszektor képes volt magát piaci alapon finanszírozni. Bár a devizabázisswap csökkenő értéke a dollárpiaci feszültségek növekedésére utal, az első negyedévben a forráskihelyezés az intuícióval ellentétes előjellel bírt ${ }^{21}$. Az eszközarányos nyereség („,ROA”) növekedése 3 negyedéven át a tendereztetett dollárlikviditás csökkentését eredményezi. A nemkonvencionális hitelnyújtási és értékpapír-vásárlási programok $\left({ }_{\text {, }}(L+S) / F X^{\prime \prime}\right)$ bővülése a 4 negyedéves késleltetés mellett a dollárlikviditás kihelyezésének csökkenésével társul - arra utalva, hogy az értékpapírpiaci programok felfutásakor a dollárlikviditás kihelyezése már lecsengőben volt. A kapott eredmények alapján látható, hogy a modell feltevései szignifikáns mértékben csak néhány negyedéves késleltetés mellett értelmezhetőek hosszú távon. A VAR-modell illesztését elvégeztük az F-mátrix többféle sorba rendezése mellett is, azonban a fenti eredményekhez kvalitatíve hasonló eredmények születtek.

${ }^{21}$ A változó ezt a tulajdonságát a strukturális F-mátrix többféle felírása mellett is megtartotta, így ez az eredmény robusztusnak tekinthető. 


\section{5. ábra \\ A strukturális VAR-modell kumulált impulzusválasz-függvényei}

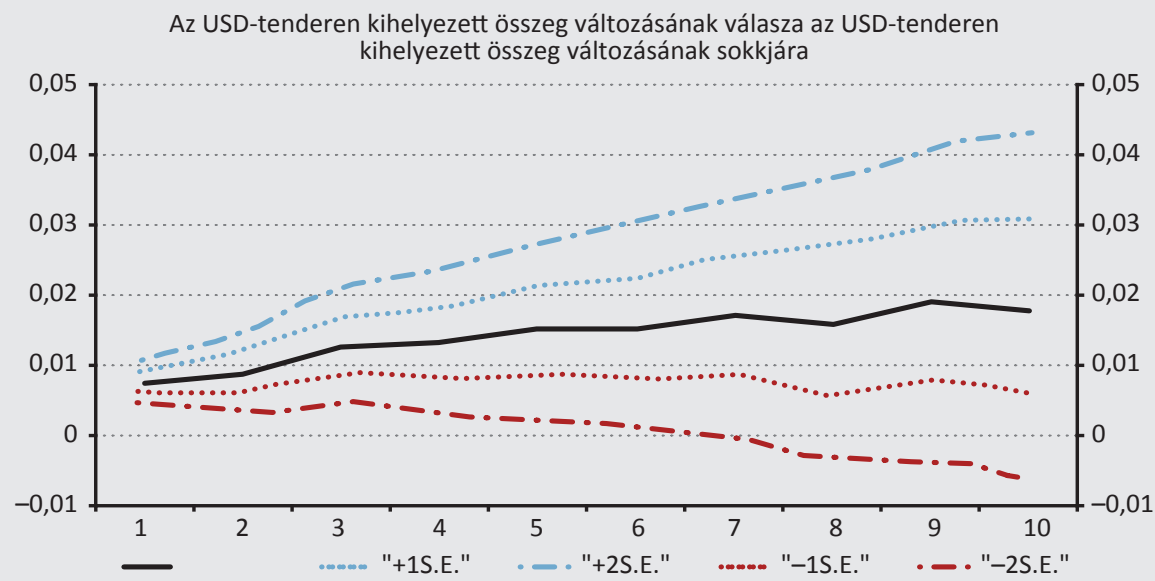

Az USD-tenderen kihelyezett összeg változásának válasza

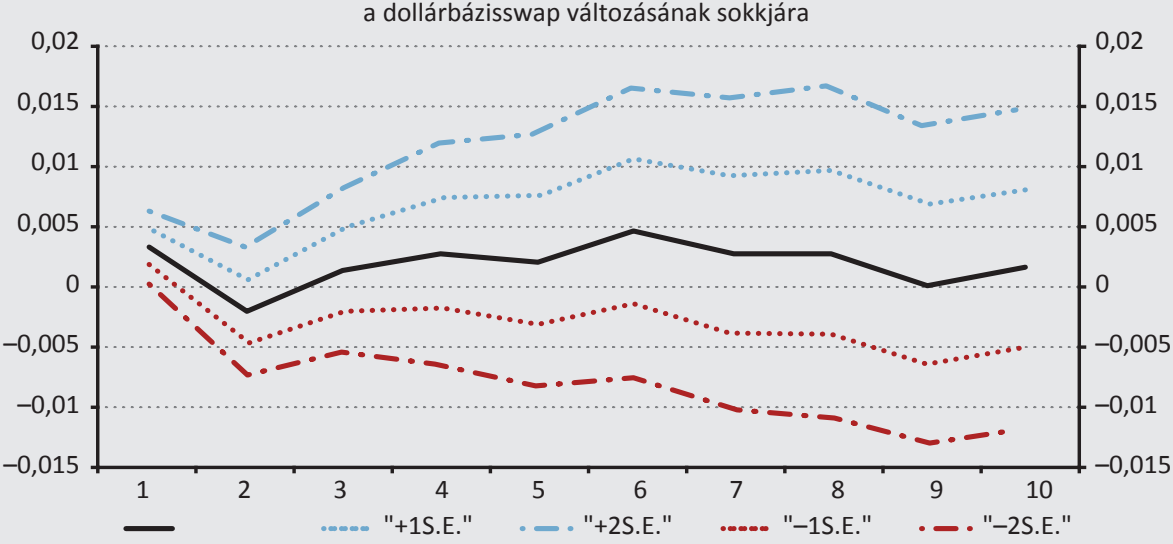

Az USD-tenderen kihelyezett összeg változásának válasza az eurozónán kívüli források változásának sokkjára

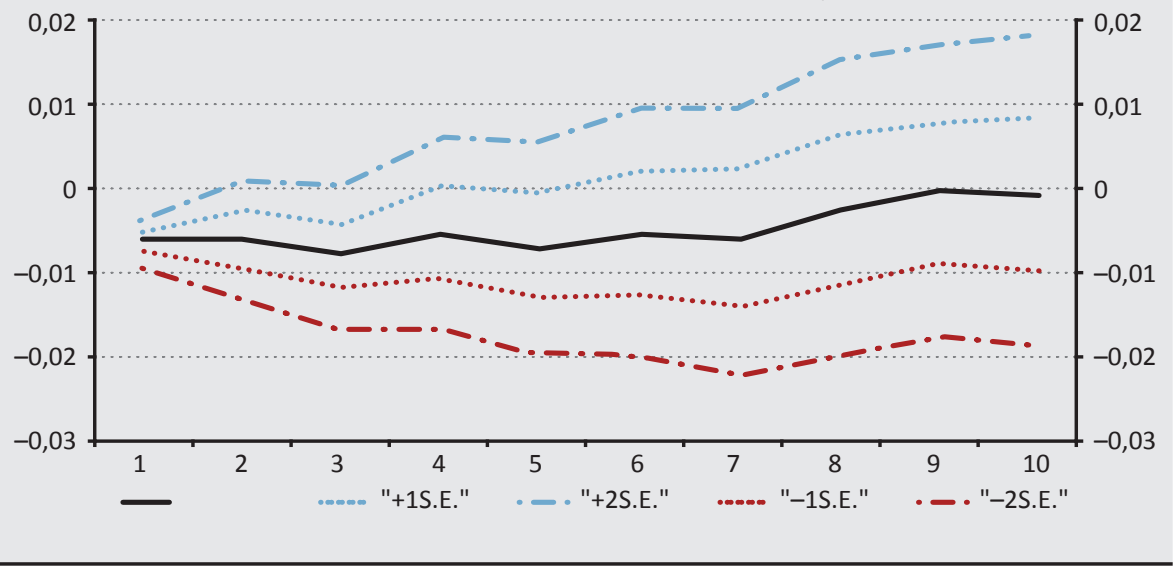




\section{5. ábra (folytatás) \\ A strukturális VAR-modell kumulált impulzusválasz-függvényei}

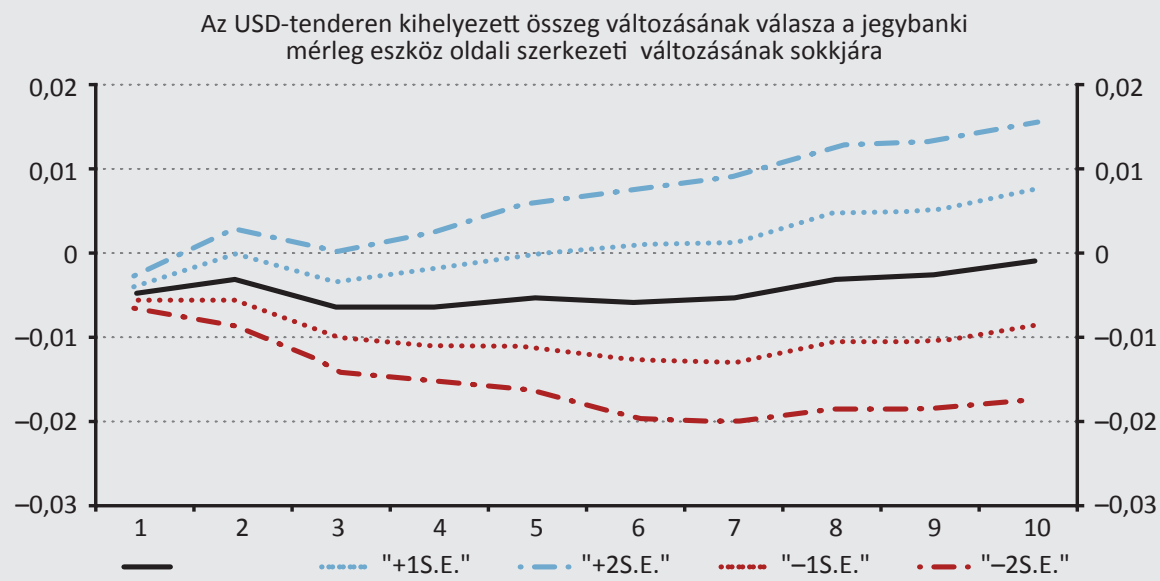

Az USD-tenderen kihelyezett összeg változásának válasza a ROA változásának sokkjára

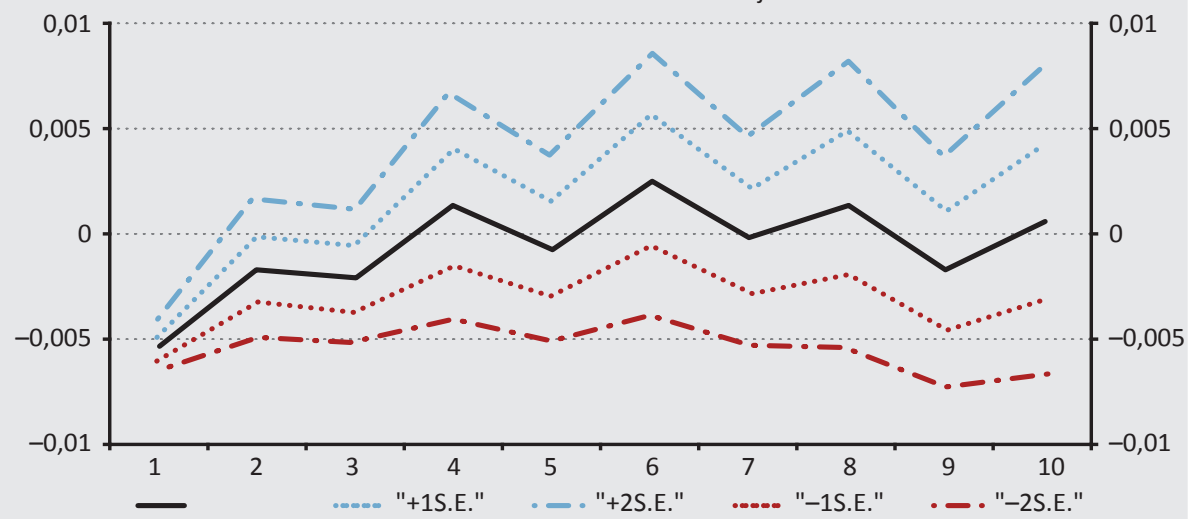

Megjegyzés: A fekete folytonos vonalak az impulzusválasz-függvényeket jelölik, míg $68 \%$ ( \pm 1 S.E.) és $95 \%$ ( \pm 2 S. E.) konfidenciaintervallumok Albrizio et al. (2020) nyomán.

Forrás: Eviews11 szoftverrel szerkesztve 
Az elvégzett varianciadekompozíciók (6. ábra) alapján elmondható, hogy az EKB által kihelyezett dollárlikviditás változásának varianciájára több negyedéven át is hatást gyakorolnak a modellben szereplő változók, közel 70 százalékos mértékben. Az eurozónán kívüli források súlya a kezdeti 27 százalékról a második negyedévre 20 százalék közelébe csökken, ami hasonló a bázisswap és a ROA változásainak a súlyához. Eközben a jegybanki mérleg szerkezetének jelentősége mindvégig 10 és 15 százalék között maradt.

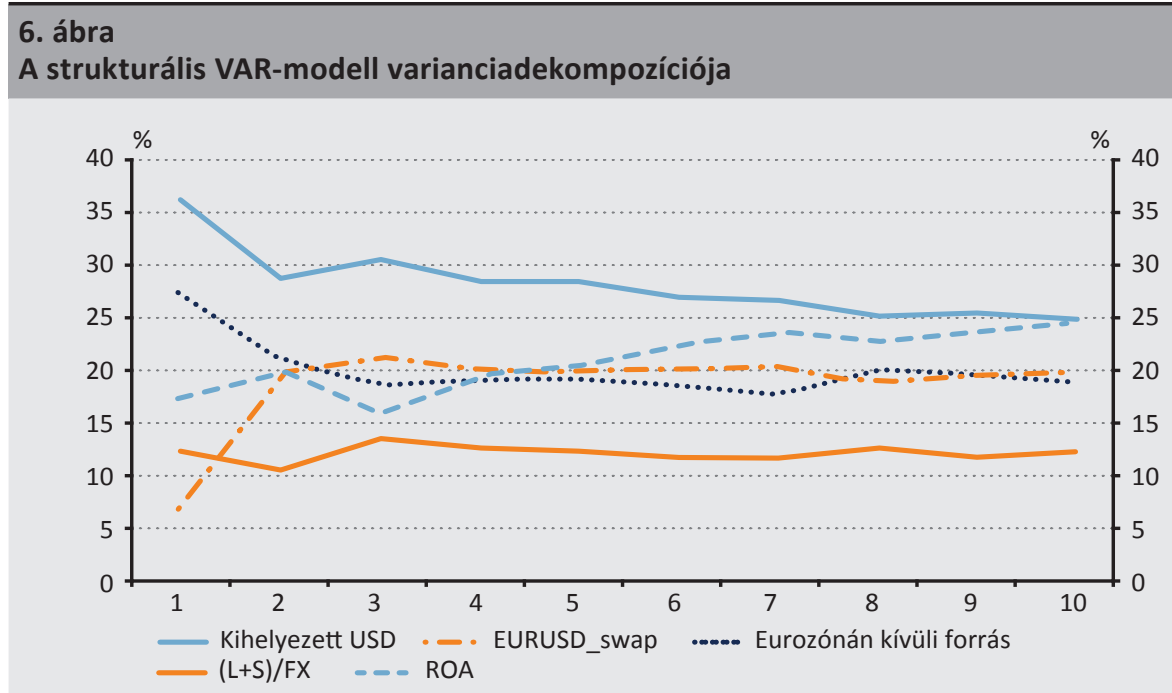

Forrás: Eviews11 szoftverrel szerkesztve

\section{5. Összegzés}

Munkánk során előbb áttekintettük azokat a megállapodásokat, amelyek eredményeképpen az egyes vezető jegybankok devizalikviditáshoz juttatták egymást 2007 decembere után, hogy így feleljenek meg a „végső mentsvár” szerepüknek a megfelelő mértékű devizalikviditás biztosítása terén is. Ezt követően vázoltuk fel elméleti modellünket és ismertettük a vizsgálatba bevont adatokat. A modellben megfogalmazott állításokat a hosszú távú kapcsolatokat vizsgáló strukturális vektor-autoregresszióval elemeztük.

Összességében megállapítható, hogy az általunk felírt modell igazolásra került, az eurozóna hitelintézetei leginkább abban az esetben fordultak az EKB-hoz dollárban denominált devizalikviditásért, amikor nehézzé vált az eurozónán kívüli forrásbevonás, csökkent az eszközarányos eredményük vagy feszültségek keletkeztek a dollárpiacon. Ezzel párhuzamosan érződött az euróban történő hitelnyújtás és értékpapír-felhalmozás hatása is. Ezzel megerősíthetjük az elméleti modellel kapcso- 
latban megfogalmazott elméleti elvárásokat is, miszerint a hitelintézeteknek valóban a piaci zavarok, a nemzetközi tőkeáramlás hagyományos csatornáinak befagyása miatt lett szüksége a jegybankok között létrejövő swapmegállapodásokon keresztül elérhető devizaforrásra.

Úgy tűnik, hogy ez a piaci hiba nem korlátozódott kizárólag a 2007-2009-es globális pénzügyi válság időszakára, hanem a hatások kimutathatóak egy, az elmúlt 12 évet leíró mintán is. Erre utal, hogy bár a vezető jegybankok már több alkalommal is kísérletet tettek a jegybankközi swapmegállapodások felfüggesztésére a hitelintézetek devizalikviditás-igényének átmeneti elapadására hivatkozva, ezeket a programokat újra és újra el kellett indítani, míg napjainkra nagyjából a rendes üzletmenet részévé váltak. Mindez jól érzékelteti azt a folyamatot is, ahogyan a kezdetben átmenetinek gondolt „,nemkonvencionális” monetáris politika filozófiája és eszköztára mára dominánssá vált a világ jegybankjainak múködésében.

\section{Felhasznált irodalom}

Ács Attila (2011): A likviditás dimenziói. Hitelintézeti Szemle, 10(3): 241-261.

Aizenman, J. - Cheung, Y-W. - Qian, X. (2020): The currency composition of international reserves, demand for international reserves, and global safe assets. Journal of International Money and Finance, 102(April): 102120. https://doi.org/10.1016/j.jimonfin.2019.102120

Albrizio, S. - Choi, S. - Furceri, D. - Yoon, C. (2020): International bank lending channel of monetary policy. Journal of International Money and Finance, 102(April): 102124. https:// doi.org/10.1016/j.jimonfin.2019.102124

Aldasoro, I. - Ehlers, T. - Eren, E. (2019): Global Banks, Dollar Funding, and Regulation. BIS Working Papers No 708, Bank of International Settlements, May. https://doi.org/10.2139/ ssrn.3368973

Allen, F. - Babus, A. (2009): Networks in Finance. In: Kleindorfer, P. - Wind, J. - Gunther, R.E. (eds.): Network Challenge, The Strategy, Profit, and Risk in an Interlinked World, Pearson Prentice Hall, pp. 367-382. https://doi.org/10.2139/ssrn.1094883

Allen, W.A. - Moessner, R. (2010): Central bank co-operation and international liquidity in the financial crisis of 2008-9. BIS Working Papers No 310, Bank of International Settlements. https://doi.org/10.2139/ssrn.1631791

Alvarez, I. - Casavecchia, F. - De Luca, M. - Duering, A. - Eser, F. - Helmus, C. - Hemous, C. (2017): The Use of the Eurosystem's Monetary Policy Instruments and Operational Framework since 2012. ECB Occasional Paper 188, European Central Bank. https://doi. org/10.2866/112727 
Ananda, K. - Gaib, P. - Marsilid, M. (2012): Rollover risk, network structure and systemic financial crises. Journal of Economic Dynamics and Control, 36(8): 1088-1100. https:// doi.org/10.1016/j.jedc.2012.03.005

Antal Judit - Gereben Áron (2011): Feltörekvő országok devizatartalék-stratégiái - a válságon innen és túl. MNB-szemle, 2011(1): 7-19. https://www.mnb.hu/letoltes/antal-gereben.pdf

Avdjiev. S. - Subelyte, A. - Takáts, E. (2016): The ECB's QE and euro cross-border bank lending. BIS Quarterly Review, Bank for International Settlements, September. https://www.bis. org/publ/qtrpdf/r_qt1609h.htm. Letöltés ideje: 2020. március 10.

Baker, C. (2013): The Federal Reserve's Use of International Swap Lines. Arizona Law Review, 55: 603-654. https://doi.org/10.2139/ssrn.2226708

Banai Ádám - Kollarik András - Szabó-Solticzky András (2015): A deviza/forint devizaswappiac topológiája. Hitelintézeti Szemle, 14(2): 128-157. https://hitelintezetiszemle.mnb. hu/letoltes/5-banai-kollarik-szabo.pdf

Berlinger Edina - Michaletzky Márton - Szenes Márk (2011): A fedezetlen bankközi forintpiac hálózati dinamikájának vizsgálata a likviditási válság elött és után. Közgazdasági Szemle, 58(március): 229-252.

BIS (2011): Global liquidity - concept, measurement and policy implications. BIS CGFS Publications No 45, Bank of International Settlements, November. https://www.bis.org/ publ/cgfs45.pdf. Letöltés ideje: 2020. március 10.

Blanchard, O.J. - Quah, D. (1989): The Dynamic Effects of Aggregate Demand and Supply Disturbances. The American Economic Review, 79(4): 655-673.

Bordo, M.D. - Humpage, O.F. - Schwartz, A.J. (2015): The Evolution of the Federal Reserve Swap Lines since 1962. IMF Economic Review, 63(2): 353-372. https://doi.org/10.1057/ imfer.2015.11

Brophy, T. - Herrala, N. - Jurado, R. - Katsalirou, I. - Le Quéau, L. - Lizarazo, C. - O’Donnell, S. (2019): Role of cross currency swap markets in funding and investment decisions. ECB Occasional Paper Series No 228, European Central Bank, August. https://www.ecb.europa. eu//pub/pdf/scpops/ecb.op228 bb3e50120a.en.pdf. Letöltés ideje: 2020. március 10.

Csávás Csaba - Szabó Rezső (2010): A forint/deviza FX-swap szpredek mozgatórugói a Lehman-csőd utáni időszakban. Hitelintézeti Szemle, 9(6): 566-580.

Destais, C. (2016): Central Bank Currency Swaps and the International Monetary System. Emerging Markets Finance and Trade, 52(10): 2253-2266. https://doi. org/10.1080/1540496X.2016.1185710

EKB (2008): EU Banking Structures. European Central Bank, October https://www.ecb. europa.eu/pub/pdf/other/eubankingstructures2008en.pdf. Letöltés ideje: 2020. március 10. 
EKB (2019): The international role of the euro. European Central Bank, June. https://www. ecb.europa.eu/pub/ire/html/ecb.ire201906 f0da2b823e.en.html. Letöltés ideje: 2020. április 2 .

Engelberth István - Sági Judit (2017): Az Új selyemút kezdeményezés szerepe, céljai. Külügyi Szemle, 16(3): 85-104.

Frankel, J. (2011): Monetary Policy in Emerging Markets, in: Friedman, B.M. - Woodford, M. (eds.): Handbook of Monetary Economics, Elsevier, pp. 1441-1499.

Ivashina, V. - Scharfstein, D S. - Stein J.C. (2015): Dollar Funding and the Lending Behavior of Global Banks. Quarterly Journal of Economics, 130(3): 1241-1281. https://doi. org/10.1093/qje/qjv017

Kick, T. - Koetter, M. - Storz, M. (2018): Cross-border transmission of emergency liquidity, Journal of Banking and Finance, 113: 105300. https://doi.org/10.1016/j. jbankfin.2018.02.006

Kiss, G.D. - Ampah, I.K. (2018): Macroeconomic Volatility and Capital Flights in Sub-Saharan Africa: A Dynamic Panel Estimation of some Selected HIPC Countries. Mediterranean Journal of Social Sciences, 9(5): 165-176. https://doi.org/10.2478/mjss-2018-0148

Lütkepohl, H. - Kratzig, M. (2004): Applied Time Series Econometrics. Cambridge University Press, Cambridge. https://doi.org/10.1017/CBO9780511606885

Madura, J. (2008): International Financial Management. Thompson.

Mák István - Páles Judit (2009): Az FX-swap piac szerepe a hazai pénzügyi rendszerben. MNB-Szemle, 2009(5): 23-32. https://www.mnb.hu/letoltes/mak-pales.pdf

Obstfeld, M. - Shambaugh J. C. - Taylor, A. M. (2009): Financial Instability, Reserves, and Central Bank Swap Lines in the Panic of 2008. American Economic Review, 99(2): 480-486. https://doi.org/10.1257/aer.99.2.480

Páles Judit - Kuti Zsolt - Csávás Csaba (2010): A devizaswapok szerepe a hazai bankrendszerben és a swappiac válság alatti múködésének vizsgálata. MNB-tanulmányok 90, Magyar Nemzeti Bank. https://www.mnb.hu/letoltes/mt-90.pdf. Letöltés ideje: 2020. március 10.

Pelle Anita - Végh Marcell (2019): Hogyan változott az euróövezet a kezdetek óta? Pénzügyi Szemle, 64(1): 127-145.

Seghezza, E. (2018): Can swap line arrangements help solve the Triffin dilemma? How? The World Economy, 41(10): 2691-2708. http://doi.org/10.1111/twec.12669

Takáts, E. - Temesvary, J. (2020): The currency dimension of the bank lending channel in international monetary transmission. Journal of International Economics, 125(7): 103309. http://doi.org/10.1016/j.jinteco.2020.103309 


\section{Melléklet}

Maximum likelihood via Newton-Raphson (analytic derivatives)

Model: e = Phi*Fu where E[uu']=I

\begin{tabular}{|c|c|c|c|c|}
\hline $\begin{array}{l}\text { 4. táblázat } \\
\text { Strukturális }\end{array}$ & cslés eredn & & & \\
\hline \multicolumn{5}{|l|}{$F=$} \\
\hline$C(1)$ & 0 & 0 & 0 & 0 \\
\hline$C(2)$ & $C(6)$ & 0 & 0 & 0 \\
\hline$C(3)$ & $C(7)$ & $C(10)$ & 0 & 0 \\
\hline$C(4)$ & $C(8)$ & $C(11)$ & $C(13)$ & 0 \\
\hline \multirow[t]{2}{*}{$C(5)$} & $C(9)$ & $C(12)$ & $C(14)$ & $C(15)$ \\
\hline & Coefficient & Std. Error & z-Statistic & Prob. \\
\hline$C(1)$ & 0,024857 & 0,002650 & 9,380826 & 0,0000 \\
\hline$C(2)$ & 0,011785 & 0,010943 & 1,076922 & 0,2815 \\
\hline$C(3)$ & 0,019235 & 0,004873 & 3,947205 & 0,0001 \\
\hline$C(4)$ & 0,625060 & 0,097028 & 6,442088 & 0,0000 \\
\hline$C(5)$ & 0,005552 & 0,003701 & 1,500050 & 0,1336 \\
\hline$c(6)$ & 0,072107 & 0,007687 & 9,380829 & 0,0000 \\
\hline$c(7)$ & $-0,022397$ & 0,003721 & $-6,019773$ & 0,0000 \\
\hline$C(8)$ & $-0,052148$ & 0,070311 & $-0,741673$ & 0,4583 \\
\hline$C(9)$ & 0,018413 & 0,003082 & 5,975096 & 0,0000 \\
\hline$C(10)$ & 0,018928 & 0,002018 & 9,380830 & 0,0000 \\
\hline$C(11)$ & 0,335420 & 0,060285 & 5,563905 & 0,0000 \\
\hline$C(12)$ & $-0,011781$ & 0,002017 & $-5,842328$ & 0,0000 \\
\hline$C(13)$ & 0,321955 & 0,034321 & 9,380830 & 0,0000 \\
\hline$C(14)$ & $-0,004081$ & 0,001517 & $-2,690743$ & 0,0071 \\
\hline$C(15)$ & 0,009637 & 0,001027 & 9,380830 & 0,0000 \\
\hline Log likelihood & 362,9767 & & & \\
\hline \multicolumn{5}{|c|}{ Estimated S matrix: } \\
\hline 0,007579 & 0,003314 & $-0,006604$ & $-0,004399$ & $-0,005283$ \\
\hline$-0,037969$ & 0,160091 & $-0,082201$ & $-0,094112$ & 0,026249 \\
\hline 0,012097 & $-0,015354$ & 0,003329 & $-0,027091$ & 0,002315 \\
\hline 0,119286 & 0,068561 & 0,135037 & 0,081387 & 0,003683 \\
\hline 0,009802 & 0,013461 & $-0,011657$ & $-0,000911$ & 0,010490 \\
\hline \multicolumn{5}{|c|}{ Estimated F matrix: } \\
\hline 0,024857 & 0,000000 & 0,000000 & 0,000000 & 0,000000 \\
\hline 0,011785 & 0,072107 & 0,000000 & 0,000000 & 0,000000 \\
\hline 0,019235 & $-0,022397$ & 0,018928 & 0,000000 & 0,000000 \\
\hline 0,625060 & $-0,052148$ & 0,335420 & 0,321955 & 0,000000 \\
\hline 0,005552 & 0,018413 & $-0,011781$ & $-0,004081$ & 0,009637 \\
\hline
\end{tabular}

